\title{
Reduction of Color Intensity from Textile Dye Wastewater Using Microorganisms: A Review
}

\author{
Md. Rayhan Sarker*, Manjushree Chowdhury and Amal Kanti Deb \\ Institute of Leather Engineering \& Technology, University of Dhaka-1209, Bangladesh \\ *Corresponding author
}

\section{A B S T R A C T}

\begin{tabular}{|l|}
\hline Ke y w o r d s \\
Reduction, Color \\
Intensity, Textile Dye, \\
Wastewater \\
\hline Article Info \\
\hline Accepted: \\
22 January 2019 \\
Available Online: \\
10 February 2019 \\
\hline
\end{tabular}

Nowadays, synthetic dyes are widely used in textile, leather, cosmetics, paper, food and pharmaceutical industries instead of natural dyes due to its availability, stability, low cost and color intensity which emerges a new problem of residual color in the discharged effluent. Improper discharge of dye effluent in aqueous ecosystems is aesthetically unpleasant and impedes photosynthetic activity reducing sunlight penetration, dissolved oxygen concentration and water quality in total. Recalcitrant azo dyes which are mostly used in textile industries are not exhaustively removed from effluent by the existing effluent treatment plant. Biological method has gained momentum over physical and chemical process to remove color of dyes because of economic viability, ecofriendly and suitable for wide range of dyes. This review primarily focuses on color removal efficiency of different organisms, its mechanism and several responsible physicochemical parameters for dye removal.

\section{Introduction}

Water pollution has gained a paramount importance due to the industrial effluents. Textile industries consume large quantities of water in wet processing operations generating huge quantities of dyestuffs.

More than 10,000 dyes are used in the textile industry and approximately 28,000 tonnes of dyes are being discharged into the public drains without proper treatment that eventually go into the river (Hsueh et al., 2005). $10 \%$ of dyes are lost during coloration process and $2 \%$ of these are directly discharged in aqueous effluent (Easton, 1995). Azo dyes are widely used among synthetic dyes in the textile industry and represent about $80 \%$ of commercial dyes produced in the world with an annual production of $7 \times 10^{5}$ tonnes (Fu and Viraraghavan, 2001). The concentration of dyes in wastewater from textile dyeing industry can vary from 10 to $250 \mathrm{mg} / \mathrm{l}$ (O’Neill et al., 1999) whereas in another research it was reported that the concentrations may as high as $1,500 \mathrm{mg} / \mathrm{l}$ (Pearce et al., 2003).

The release of these dyes in large quantities is a serious threat to the environment. Besides aesthetic and problem towards photosynthetic process, azo dyes also have an adverse impact in terms of total organic carbon (TOC), biological oxygen demand (BOD) and 
chemical oxygen demand (COD) (Saratale et al., 2009) and many of its metabolites are toxic, carcinogenic and mutagenic (Myslak and Bolt, 1998). Moreover various research reveal that the toxic effects of dyes have a major influence over the germination rates and biomass of several plant species (Ghodake $e t$ al., 2009). As a result, treatment of industrial dye effluents and their metabolites is necessary prior to their final discharge to the environment. Therefore this topic is gaining great interest of many researchers to study the pros and cons of color removal.

There are three methods to treat the industrial effluent such as physical, chemical and biological method. Physical method involve the use of bio-sorbents, coagulants and filtration techniques. Activated carbon, alumina, silica gel, clays, chitin, chitosan, zeolite, rice husk, orange peels, peat, sawdust, red mud, maize cobs, fly ash, and bagasse pith which are known as bio-sorbents, are being used to remove dyes from waste water (Gupta, 2009).

The most drawback of solid adsorbents is that adsorbents contain toxic dyes on their surfaces generating sludge as secondary pollutant solid waste. Chemical methods such as ozonation, fenton oxidation, electrochemical oxidation, ultrasonic chemical oxidation and irradiation oxidation has limited usability for the treatment of dyes due to high cost of the electricity, radiation, and ozone (Pearce et al., 2003; Esteves and Silva, 2004). On the other hand, microorganisms for decolorizing dyes effluent is considered relatively cost effective.

Moreover biological treatment are ecofriendly because it exhaustively removes pollutants from the effluent. In this review, we will discuss about the different processes of dye removal with microbial de-colorization process and several parameters related to the mechanism.
Physico-chemical characteristics of textile raw wastewater and its impact towards degradation

Different azo dyes, salts and metals, along with other compounds that make textile raw wastewater very difficult to decolorize from wastewater containing simple dye mixtures and sodium chloride (Saratale et al., 2009; Alinsafi et al., 2006). Polyvinyl alcohol (PVA), carboxymethyl cellulose, surfactants, organic processing acids, sulfide, formaldehyde, detergents, and oil and dispersants that are used in textile industry either to give strength to the fiber or to improve the adsorption of dyes on the fiber (Rosli and Habibah, 2006) which are not readily biodegradable and can be toxic to the microbial cultures. Some characteristics of raw textile wastewater that are important from the viewpoint of de-colorization are discussed in detail here.

Dyes with methyl, methoxy, nitro or sulpho groups are found to be degraded very difficult as compared with dyes which have hydroxyl or amino groups (Nigam et al., 1996). On the other hand, direct dyes are easily degraded comparing with acid and reactive dyes (Saratale et al., 2009) whereas high molecular weight dyes are degraded slowly than low molecular weight dyes. Thus the composition of the azo dyes has a great influence over the de-colorization of dyes. The effluents are found toxic, xenobiotic and carcinogenic to aquatic life where dyes are released in the textile wastewater (Tüfekci et al., 2007; Adinew, 2012). In order to improve the fixation of dyes on fabrics $\mathrm{NaNO}_{3}, \mathrm{NaCl}$ and $\mathrm{Na}_{2} \mathrm{SO}_{4}$ salts are generally added to the baths for improving the fixation of dyes. High concentrations of salts can reduce the rate of biodegradation of dyes as salts can cause plasmolysis and reduce biological activity (Manu and Chaudhari, 2003). Electrophilic agents such as nitrate and sulfate compete 
with the dye molecule for electrons from azoreductases, causing negative effect on the de-colorization of dyes (Meng et al., 2012). Metal complex dyes or chemicals existing metals are also used in the dyeing process. It was reported in an article that about 30\% metal complex dyes are used in dyeing wool and $40 \%$ for dyeing polyamide (Hunger, 2003). Various metals such as $\mathrm{Cd}, \mathrm{Cr}, \mathrm{Co}, \mathrm{Cu}$, $\mathrm{Hg}, \mathrm{Ni}, \mathrm{Mg}, \mathrm{Fe}$ and $\mathrm{Mn}$ are found in the raw textile effluents which are found to inhibit microbial growth and enzymatic activities (Saranraj et al., 2010). In addition, temperature is a great factor for decolorization. The temperature of the dye effluent can be as high as $70^{\circ} \mathrm{C}$ which inhibits the microbial activities (Saratale et al., 2009; Abu-Ghunmi and Jamrah, 2006). The favorable condition for dye degrading of microbes is $30-40{ }^{\circ} \mathrm{C}$. But some bacterium Anoxybacillus rupiensis was identified that can de-colorize at about $60^{\circ} \mathrm{C}$. In general high temperature reduces the rate of de-colorization and hence a pretreatment of cooling is necessary for wastewater treatment through biological process. Another important driver of textile wastewater treatment is fluctuating $\mathrm{pH}$ that can vary on the particular dye process. It may be highly alkaline, neutral or acidic depending on the nature of the salts and dyes (Imran et al., 2014). It has been recorded that the $\mathrm{pH}$ of the dye-containing wastewater can change the rate of degradation of the dyes (Hussain et al., 2013). Hence either the $\mathrm{pH}$ of the wastewater should be adjusted according to the microbial culture or else requires the use of microbial strains that are capable of decolorization. On the other hand, Biological oxygen demand (BOD) and chemical oxygen demand (COD) are also important factors for biodegradation process. BOD refers to the amount of oxygen that would be consumed if all the organics are oxidized by the biological process (ReVelle and ReVelle, 1988) while the COD is the amount of oxygen consumed for oxidizing organic and inorganic contaminants chemically. BOD (800mg L-1) and COD (2,300 mg L-1) values are observed in the textile wastewater (Jang et al., 2007) whereas in another research it was recorded as COD values in the range of 1,067-2,430 and BOD values in the range 163-645 mg L-1 (Yusuff and Sonibare, 2004). Generally, easily decomposed organic compounds by microbes can enhance the rate of dye removal from wastewater by serving as source of reducing equivalent (NADH, NADPH) which are needed for the azo reductases to reduce azo bonds; but textile wastewater contains organics (oil, waxes, PVA and formaldehyde) which are not easily decomposed by microbes and thus their presence in wastewater can suppress microbial activities (Imran et al., 2014).

\section{Preference of biological treatment relative to physicochemical methods}

Several physical/chemical methods, such as adsorption, chemical precipitation, photolysis, chemical oxidation and reduction, electrochemical treatment, have been used for the removal of dyes from wastewater (Saratale et al., 2011) depicted in the Fig. 1.

Coagulation-flocculation based physical methods of dyes are effective for the removal of mainly sulphur and disperse dyes, but exhibit very low efficiency for acid, direct, reactive and vat dyes (Saratale et al., 2011). Moreover, huge amount of sludge and lower color removal efficiency limit the application of these techniques (Vandevivere et al., 1998). In chemical oxidation methods, various oxidizing agents such as ozone $\left(\mathrm{O}_{3}\right)$, hydrogen peroxide $\left(\mathrm{H}_{2} \mathrm{O}_{2}\right)$ and permanganate $\left(\mathrm{MnO}_{4}\right)$ are used which modify the chemical composition of compound dye molecules that make susceptible to degradation (Metcalf, 2003). Ozonation, advanced oxidation process (AOP), fenton reaction are widely used for the removal of dye color. 
Table.1 Current available technologies for color removal with advantages and disadvantages (Pearce et al., 2003)

\begin{tabular}{|l|l|l|}
\hline $\begin{array}{l}\text { Physical and/or chemical } \\
\text { methods }\end{array}$ & Advantages & Disadvantages \\
\hline Oxidation & Rapid process & $\begin{array}{l}\text { High energy costs and } \\
\text { formation of by-products }\end{array}$ \\
\hline Adsorption & $\begin{array}{l}\text { Good removal of wide range } \\
\text { of dyes }\end{array}$ & $\begin{array}{l}\text { Absorbent requires } \\
\text { regeneration or disposal }\end{array}$ \\
\hline Membrane technologies & Removal of all types of dyes & $\begin{array}{l}\text { Concentrated } \\
\text { production }\end{array}$ \\
\hline Coagulation/flocculation & Economically feasible & High sludge production \\
\hline
\end{tabular}

Table.2 De-colorization of dyes from industrial effluent using microorganisms-studies reported

\begin{tabular}{|c|c|c|c|}
\hline Name of the dyes & Organisms used & Comments & Reference \\
\hline Ramazol black b & Pseudomonas putida & $\begin{array}{l}97.12 \% \text { de-colorization } \\
\text { efficiency (DE), } 48 \mathrm{~h}, 35^{\circ} \mathrm{C} \text {, } \\
\text { pH 7.00, } 300 \mathrm{ppm} .\end{array}$ & (Kannan et al., 2013) \\
\hline $\begin{array}{l}\text { Reactive orange } 16, \\
\text { Reactive black } 5\end{array}$ & Lactobacillus delbruckii & $\begin{array}{l}46 \% \& 49 \% \text { DE, } 37^{\circ} \mathrm{C}, \mathrm{pH} \\
6.00,10 \mathrm{ppm} .\end{array}$ & (SitiZuraida et al., 2013) \\
\hline Red RBN & Aeromonashydrophilia & $\begin{array}{l}90 \% \text { DE, } 20-35^{\circ} \mathrm{C}, \mathrm{pH} 5.5- \\
10.00,300 \mathrm{ppm} .\end{array}$ & (Chen et al., 2003) \\
\hline Brown 3REL & Bacillus sp. VUS & $100 \% \mathrm{DE}, 50^{\circ} \mathrm{C}, \mathrm{pH} 7.00,2 \mathrm{~h}$ & (Jadhav et al., 2008) \\
\hline Reactive red 120 & Xanthomonascampestris & $60-97 \% \mathrm{DE}$ & (Khehra et al., 2005) \\
\hline Reactive blue 13 & Pseudomonas sp. & $\begin{array}{l}83.2 \% \text { DE, } 35^{\circ} \mathrm{C}, \mathrm{pH} 7.00,70 \\
\mathrm{~h}\end{array}$ & (Lin et al., 2010) \\
\hline Reactive yellow 84 & Aeromonashydrophila & $66.5 \% \mathrm{DE},, 30^{\circ} \mathrm{C}, \mathrm{pH} 7.5$ & (Hsueh et al., 2009) \\
\hline Reactive orange 16 & Bacillus genus & $\begin{array}{l}88 \% \text { DE, } 30^{\circ} \mathrm{C}, \mathrm{pH} 7-8.00, \\
24 \mathrm{~h}\end{array}$ & (Telke et al., 2009) \\
\hline Congo red & Pseudomonas sp. & $97 \%$ DE, $30^{\circ} \mathrm{C}, \mathrm{pH} 7,12 \mathrm{~h}$ & (Telke et al., 2009) \\
\hline Direct red 5B & Comamonassp. UVS & $100 \% \mathrm{DE}, 40^{\circ} \mathrm{C}, \mathrm{pH} 6.5,13 \mathrm{~h}$ & (Jadhav et al., 2008) \\
\hline Acid orange 7 & Sphingomonassp. & $90 \% \mathrm{DE}, 1 \mathrm{~h}$ & (Coughlin et al., 2002) \\
\hline Dimethyl yellow & Aeromonashydrophiliavar. 24B & $54-90 \% \mathrm{DE}$ & (Idaka et al., 1978) \\
\hline Orange $1 \& 2$ & Pseudomonas sp. & $35 \%$ \& $90 \%$ DE respectively & (Kulla et al., 1983) \\
\hline C.I. Acid Orange 12 & Pseudomonas capacia $13 \mathrm{NA}$ & $90 \% \mathrm{DE}, 68 \mathrm{~h}$ & (Ogawa et al., 1986) \\
\hline Amaranth & Bacteroidesfragilis & $80 \% \mathrm{DE}$ & (Bragger et al., 1997) \\
\hline Remazol black b & Shewanellaputrefaciens & $95 \% \mathrm{DE}$ & (Willmott, 1997) \\
\hline Acid red GR & Shewanelladecolorations $\mathrm{S} 12$ & $100 \% \mathrm{DE}, 30^{\circ} \mathrm{C}$ & (Xu et al., 2007) \\
\hline Reactive orange 96 & Desulfovibriodesulfuricans & $95 \% \mathrm{DE}, 28^{\circ} \mathrm{C}$ & (Yoo et al., 2000) \\
\hline Disperse blue 79 & Bacillus fusiformisKMK5 & $100 \% \mathrm{DE}, 37^{\circ} \mathrm{C}, \mathrm{pH} 9.0,48 \mathrm{~h}$ & (Kolekar et al., 2008) \\
\hline Triphenylmethane dyes & Kurithasp. & $98 \%$ DE, 30 mins & (Sani and Banerjee, 1999) \\
\hline C.I Reactive red 22 & Pseudomonas luteola & $86.3 \mathrm{mg}$ dye $\mathrm{l}^{-1} \mathrm{~h}^{-1}$ & (Chang and Lin, 2000) \\
\hline Remazol black b & $\begin{array}{l}\text { Panibacillusazoreducenssp. } \\
\text { nov. }\end{array}$ & $98 \% \mathrm{DE}$ & (Meehan et al., 2001) \\
\hline
\end{tabular}


Fig.1 Treatment methods for the removal of dyes from wastewater effluent (Hussain et al., 2013)

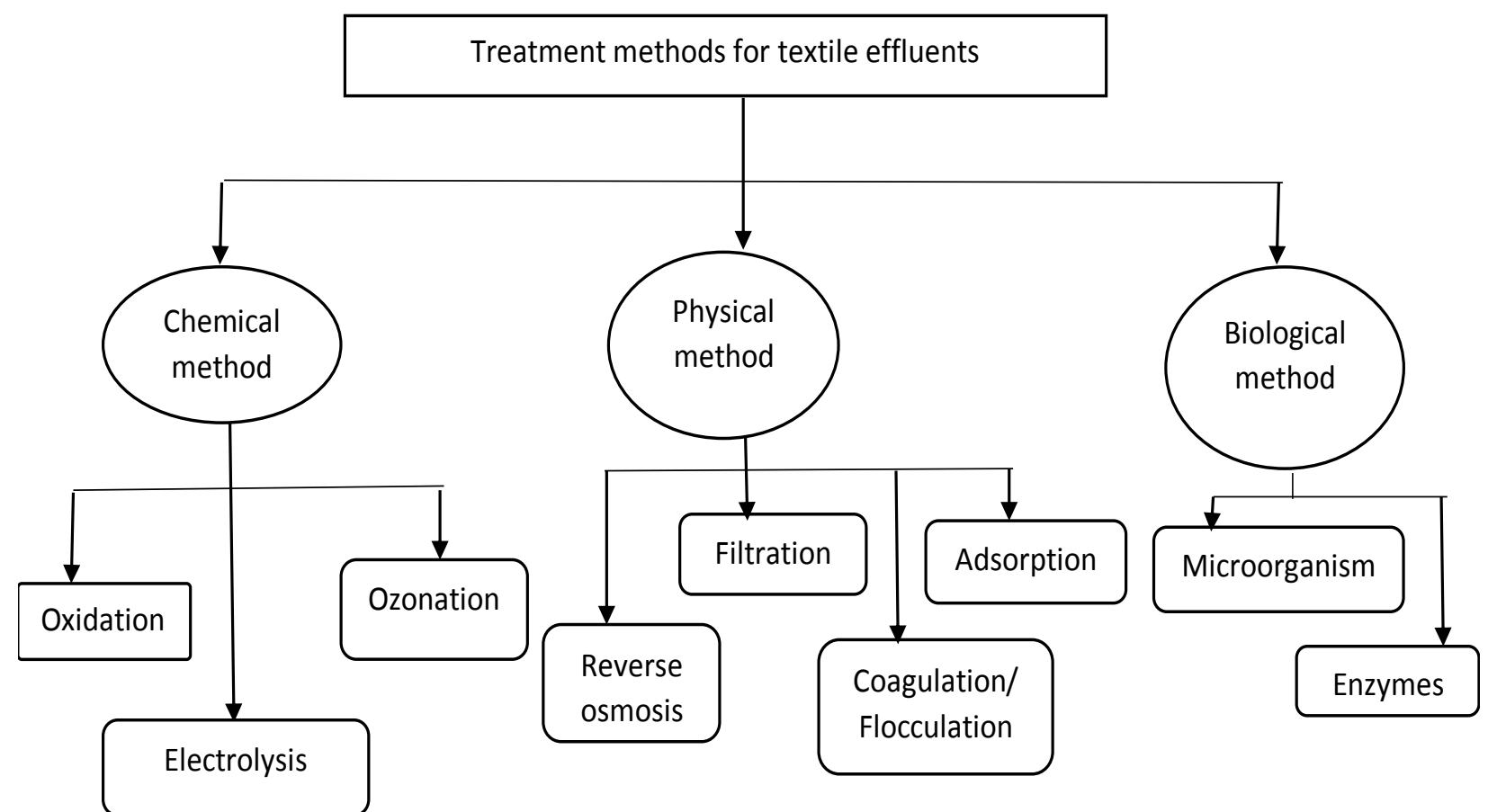

Physical and chemical methods have several drawbacks for the removal of dye color whereas biological methods have following advantages: (1) eco-friendly, (2) economical, (3) generating less sludge, (4) non-toxic end products or have complete mineralization; and (5) requiring less water consumption compared to physicochemical methods (Banat et al., 1996; Rai et al., 2005).

\section{Mechanism for color removal}

There are two mechanisms for the decoloration of azo dyes in bacterial systems (Pearce et al., 2003):

"Direct electron transfer to azo dyes as terminal electron acceptors via enzymes during bacterial catabolism, connected to ATP-generation (energy conservation)".

"A gratuitous reduction of azo dyes by the end products of bacterial catabolism, not linked to ATP-generation".

\section{Drivers for color removal}

There are several factors for dye removal such as temperature, aeration, $\mathrm{pH}$, dye structure, electron donor, redox potential and redox mediator (Pearce et al., 2003).

The optimum temperature for bacterial cell growth is about $\quad 35-45^{\circ} \mathrm{C}$ whereas some microbes can grow at $60^{\circ} \mathrm{C}$ (Pearce et al., 2003). The loss of cell viability or denaturation of the azoreductase enzyme are occurred at higher temperature (Chang et al., 2001).

Both aerobic and anaerobic conditions have great role on dye removal. The concentration of oxygen can be high by the presence of aeration and agitation which should be controlled for efficient dye removal (Chang and Lin, 2000).

Oxygen has a vital role for the cell growth of bacteria but oxygen with high redox potential 
electron acceptor can inhibit the dye reduction process (Pearce et al., 2003).

Neutral $\mathrm{pH}$ and slightly alkaline $\mathrm{pH}$ are the optimum conditions for efficient dye removal that is between 6.0 and 10 (Guo et al., 2007). The rate of color removal decreases at strongly acidic or strongly alkaline $\mathrm{pH}$.

The greater the concentration of dyes, the lower the removal efficiency because of the formation of toxic metabolites. Aromatic rings with sulfonic acid groups of reactive azo dyes impedes the growth of microorganisms at high dye concentration (Kalyani et al., 2008). Hydroxyl or amino group containing azo compounds can be easily degraded than those with a methyl, methoxy, sulpho or nitro groups (Nigam et al., 1996).

Moreover, the presence of electron donors, the more positive redox potential and the presence of redox mediator has a positive impact on dye removal process.

The residual color of dye effluent has not only aesthetic problem but also environmental pollution factor that should be taken care by the industry to make a sustainable practice.

Among different processes, microbial and enzymatic de-colorization and degradation have great advantages such as low cost and environmentally friendly over other conventional processes. The reviewed literature suggests a wide variety of microbes are suitable for de-colorization of dyes that should be considered for real life application.

At the time of de-colorization process some toxic elements such as aromatic amines and other residues may be formed which should be required further mineralization process. It is also necessary to study the genetic basis of bacteria tolerance for salts, toxic elements and heavy metals.

\section{References}

Abu-Ghunmi LN, and Jamrah AI. 2006. Biological treatment of textile wastewater using sequencing batch reactor technology. Environ Model Assess. 11:333-343.

Adinew, B., 2012. Textile effluent treatment and decolorization techniques - A review. Bulgarian Journal of Science Education. 21:3.

Alinsafi A, Da Motta M, LeBonte' S, Pons MN, Benhammou A. 2006. Effect of variability on the treatment of textile dyeing wastewater by activated sludge. Dyes Pigment.69:31-39.

Banat, I. M., P. Nigam, D. Singh, and R. Marchant. 1996. Microbial Decolorization of Textile-DyeContainting Effluents: A Review. Bioresour. Technol. 58, 217.

Bragger JL, Lloyd AW, Soozandehfar SH, Bloomfield SF, Marriott C, Martin GP. 1997. Investigations into the azo reducing activity of a common colonic microorganism. International Journal of Pharmaceutics. 157:61-71.

Chang J-S, and Lin Y-C. 2000. Fed-batch bioreactor strategies for microbial decolorization of azo dye using a Pseudomonas luteola strain. Biotechnology Progress. 16:979-985.

Chang J-S, and Lin Y-C. 2000. Fed-batch bioreactor strategies for microbial decolorization of azo dye using a Pseudomonas luteola strain. Biotechnology Progress.16:979-985.

Chang J-S, Chou C, Lin Y-C, Lin P-J, Ho JY, Hu TL. 2001. Kinetic characteristics of bacterial azo-dye decolorizationby Pseudomonas luteola. Water Research. 35(12): 2841-50.

Chen, K.-C., Wu, J.-Y., Liou, D.-J., \& Hwang, S.-C. J. 2003. Decolorization of the textile dyes by newly isolated bacterial strains. Journal of 
Biotechnology. 101(1):57-68. doi:10.1016/s0168-1656(02)00303-6.

Coughlin MF, Kinkle BK, Bishop PL. 2002. Degradation of acid orange 7 in an aerobic biofilm. Chemosphere. 46: 1119.

Easton, J. 1995. The dye maker's view. In: Cooper P, editor. Colour in dyehouse effluent. Bradford, UK: Society of Dyers and Colourists; p. 11.

Esteves M, and Silva JD. 2004. Electrochemical degradation of reactive blue 19 dye in textile wastewater. Autex World Textile Conference (4) Roubaix. $1-6$.

Fu, Y, and Viraraghavan, T. 2001. Fungal decolorization of dye wastewaters: a review. BioresourTechnol 79:251-262.

Ghodake, G. S., A. A. Telke, J. P. Jadhav, and S. P. Govindwar. 2009. Potential of Brssicajunceain Order to Treat Textile Effluent Contaminated Sites. Int. J. Phytoreme, 11: 1.

Guo, J. B., J. T. Zhou, D. Wang, C. P. Tian, P. Wang, M. S. Uddin, and H. Yu. 2007. Biocatalyst Effects of Immobilized Anthraquinone on the Anaerobic Reduction of Azo Dyes by the Salt-Tolerant Bacteria. Water Res. $41,426$.

Gupta VK, 2009. Application of low-cost adsorbents for dye removal-a review. J Environ Manag. 90:2313-2342.

Hsueh, C. C., B. Y. Chen, and C. Y. Yen. 2009. Understanding Effects of Chemical Structure on Azo Dye Decolorization Characteristics by Aeromonashydrophila. J. Hazard. Mater, 167, 995.

Hsueh, C. L., Y.H. Huang, C.C. Wang, and Chen, S. 2005. Degradation of azodyes using low iron concentration of Fenton and Fenton-like system, Chemosph. 58: 1409-1414.
Hunger K. 2003. Industrial dyes-chemistry, properties, applications. $\mathrm{VCH}$, New York

Hussain S, Maqbool Z, Ali S, Yasmeen T, Imran M, Mahmood F, Abbas F. 2013. Biodecolorization of reactive black- 5 by a metal and salt tolerant bacterial strain Pseudomonas sp. RA20 isolated from Paharang drain effluents in Pakistan. Ecotoxicol Environ Saf. 98: 331-338.

Idaka E, Ogawa T, Horitsu H, Tomoyeda M. 1978. Degradation of azo compounds by Aeromonashydrophilia var. 24B. Journal of the Society of Dyers and Colourists: 91-94.

Imran, M., Crowley, D. E., Khalid, A., Hussain, S., Mumtaz, M. W., \& Arshad, M. 2014. Microbial biotechnology for decolorization of textile wastewaters. Reviews in Environmental Science and Bio/Technology, 14(1), 73-92. doi:10.1007/s11157-014-9344-4.

Jadhav, S.U., Jadhav, U.U., Dawkar, V.V. Govindwar, S. P. 2008. Biodegradation of disperse dye brown 3 REL microbial constorium of Galactomycesgeotrichum.

BiotechnolBioproc E. 13 (2): 232-239. https://doi.org/10.1007/s12257-0070204-8.

Jadhav, U. U., V. V. Dawkar, G. S. Ghodake, and S. P. Govindwar. 2008. Biodegradation of Direct Red 5B, a Textile Dye by Newly Isolated Comamonas sp. UVS. J. Hazard. Mater. 158, 507.

Jang MS, Jung BG, Sung NC, Lee YC. 2007. Decolorization of textile plant effluent by Citrobacter sp. strain KCTC 18061P. J Gen ApplMicrobiol, 53:339-343.

Kalyani, D. C., A. A. Telke, R. S. Dhanve, and J. P. Jadhav. 2008. Ecofriendly Biodegradation and Detoxification of Reactive Red 2 Textile Dye by Newly Isolated Pseudomonas sp. SUK1. J. Hazard. Mater. 163:735. 
Kannan, S., Dhandayuthapani, K., \& Sultana, M. 2013. Decolorization and degradation of Azo dye-Remazol Black $B$ by newly isolated Pseudomonas putida. Int.J.Curr.Microbiol.App.Sci. 2(4): 108-116.

Khehra, M. S., Saini, H. S., Sharma, D. K., Chadha, B. S., \& Chimni, S. S. 2005. Comparative studies on potential of consortium and constituent pure bacterial isolates to decolorize azo dyes. Water Research. 39(20): 5135-5141. doi:10.1016/j.watres.2005.09.033.

Kolekar, Y. M., S. P. Pawar, K. R. Gawai, P. D. Lokhande, Y. S. Shouche, and K. M. Kodam.2008.Decolorization and Degradation of Disperse Blue 79 and Acid Orange 10, by Bacillus fusiformis KMK5 Isolated from the Textile Dye Contaminated Soil. Bioresour. Technol. 99: 8999.

Kulla HG, Klausener F, Meyer U, Ludeke B, Leisinger T. 1983. Interference of aromatic sulfo groups in the microbial degradation of the azo dyes Orange I and Orange II. Archives of Microbiology.135:1-7.

Lin, J., X. Zhang, Z. Li, and L. Lei. 2010. Biodegradation of Reactive Blue 13 in a Two-Stage Anaerobic/Aerobic Fluidized Beds System with a Pseudomonas sp. Isolate. Bioresour. Technol. 101, 34.

Manu B, and Chaudhari S. 2003. Decolorization of indigo and azo dyes in semicontinuous reactors with long hydraulic retention time. Process Biochem 38:1213-1221.

Meehan C, Bjourson AJ, McMullan G. 2001. Paenibacillus azoreducens sp. nov., a syntheticazo dye decolorizing bacterium from industrial wastewater. International Journal of Systematic and Evolutionary Microbiology. 51: 16811685.
Meng X, Liu G, Zhou J, Fu QS, Wang G. 2012. Azo dye decolorization by Shewanellaaquimarina under saline conditions. BioresourTechnol 114:95101.

Metcalf, E. 2003. Wastewater Engineering: Treatment and Reuse, 4th ed. McGrawHill, New York, USA.

Myslak, Z. W. and Bolt H. M. 1998. Occupational Exposure to Azo Dyes and Risk of Bladder Cancer, Zbl. Arbeitsmed. 38,310.

Nigam P, Banat IM, Singh D, Marchant R, 1996. Microbial process for the decolorization of textile effluent containing azo, diazo and reactive dyes. Process Biochem. 31:435-442.

O’Neill C, Hawkes FR, Esteves SRR, Hawkes DL, Wilcox SJ. 1999. Anaerobic and aerobic treatment of a simulated textile effluent. J ChemTechnolBiotechnol 74:993-999.

Ogawa T, Yatome C, Idaka E, Kamiya H. 1986. Biodegradation of azo acid dyes by continuous cultivation of Pseudomonas cepacia 13NA. Journal of the Society of Dyers and Colourists. 102:12-14.

Pearce CI, Lloyd JR, Guthrie JT. 2003. The removal of color from textile wastewater using whole bacterial cells: a review. Dyes Pigment 58:179-196.

Rai, H., M. Bhattacharya, J. Singh, T. K. Bansal, P. Vats, and U. C. Banerjee. 2005. Removal of Dyes from the Effluent of Textile and Dyestuff Manufacturing Industry: A Review of Emerging Techniques with Reference to Biological Treatment, Crit. Rev. Environ. Sci. Technol. 35,219.

ReVelle P, and ReVelle C. 1988. The environment: issues and choices forsociety, 3rd edn. Jones and Bartlett Publishers, Boston, 749.

Rosli M, and Habibah N. 2006. Development of biological treatment system for 
reduction of COD from textile wastewater (Doctoral dissertation, UniversitiTeknologi Malaysia, Faculty of Science)

Sani RK, and Banerjee UC. 1999. Decolorization of triphenylmethanedyes and textile and dye-stuff effluent by Kurthiasp. Enzyme and Microbial Technology: 24:433-437.

Saranraj P, Sumathi V, Reetha D, Stella D. 2010. Decolorization and degradation of direct azo dyes and biodegradation of textile dye effluent by using bacteria isolated from textile dye effluent. J Ecobiotechnol. 2:7-11.

Saratale RG, Saratale GD, Kalyani DC, Chang JS, Govindwar SP, 2009. Enhanced decolorization and biodegradation of textile azo dye Scarlet $\mathrm{R}$ by using developed microbial consortium-GR. Bioresour Technol. 100:2493-2500.

Saratale, R. G., Saratale, G. D., Chang, J. S., \&Govindwar, S. P. (2011). Bacterial decolorization and degradation of azo dyes: A review. Journal of the Taiwan Institute of Chemical Engineers, 42(1), 138-157. doi:10.1016/j.jtice.2010.06.006

SitiZuraida, M., Nurhaslina, C.R., Ku Halim Ku Hamid. 2013. Removal of Synthetic Dyes from Wastewater by Using Bacteria, Lactobacillus delbruckii. International Refereed Journal of Engineering and Science. 2(5):01-07.
Telke, A. A., D. C. Kalyani, V. V. Dawkar, and S. P. Govindwar. 2009. Influence of Organic and Inorganic Compounds on Oxidoreductive Decolorization of SulfonatedAzo Dye C.I. Reactive Orange 16. J. Hazard. Mater. 172, 298.

Tüfekci, N., N. Sivri and I. Toroz. 2007. Pollutants of Textile Industry Wastewater and Assessment of its Discharge Limits by Water Quality Standards. Turkish Journal of Fisheries and Aquatic Sciences: 7.

Vandevivere, P. C., R. Bianchi, and W. Verstraete. 1998. Treatment and Reuse of Wastewater from the Textile Wetprocessing Industry: Review of Emerging Technologies. J. Chem. Technol. Biotechnol. 72, 289.

Willmott NJ. 1997. The use of bacteriapolymer composites for the removal of colour from reactive dye effluents. $\mathrm{PhD}$ thesis, UK: University of Leeds.

Xu, M., J. Guo, and G. Sun. 2007. Biodegradation of Textile Azo Dye by Shewanelladecolorationis S12 under Microaerophilic Conditions. Appl. Microbiol. Biotechnol.76: 719.

Yoo, E. S., J. Libra, and L. Adrian. 2000. Mechanism of Decolorization of Azo Dyes in Anaerobic Mixed Culture. J. Environ. Eng., 127, 844.

Yusuff RO, and Sonibare JA. 2004. Characterization of textile industries' effluents in Kaduna, Nigeria and pollution implications. Glob Nest: Int J. 6:212-221.

\section{How to cite this article:}

Md. Rayhan Sarker, Manjushree Chowdhury and Amal Kanti Deb. 2018. Reduction of Color Intensity from Textile Dye Wastewater Using Microorganisms: A Review. Int.J.Curr.Microbiol.App.Sci. 8(02): 3407-3415. doi: https://doi.org/10.20546/ijcmas.2019.802.397 